PIOTR DOMINIK

Szkoła Główna Turystyki i Rekreacji w Warszawie, Polska - Warsaw School of Tourism and Hospitality Management, Poland

\title{
Edukacyjna rola szlaków kulinarnych
}

\section{Educational Role of Culinary Trails}

Streszczenie: Celem opracowania jest wskazanie roli, jaką w procesie edukacji turystów odgrywają szlaki kulinarne, zarówno występujące w sposób naturalny w przestrzeni antropogenicznej, jak i wyznaczone przez organizatorów turystyki. Szlaki kulinarne dają turystom możliwość bezpośredniego obcowania $\mathrm{z}$ wiedzą na temat wybranych produktów kulinarnych. Stwarzają także warunki do aktywnego uczestnictwa i zdobywania umiejętności posługiwania się rozmaitymi urządzeniami, jak również kształtują kompetencje społeczne poprzez osobisty kontakt z pojedynczymi osobami oraz społecznościami wytwarzającymi żywność. W opracowaniu zwrócono szczególną uwagę na rolę bezpośredniego poznania i obserwacji oraz uczestnictwa w wydarzeniach mających miejsce na szlaku kulinarnym. Wskazano na powiązanie zagadnienia edukacji z turystyką oraz uwypuklono miejsce szlaków kulinarnych w turystyce edukacyjnej. Przeanalizowano, które elementy szlaków i w jaki sposób oddziałują edukacyjnie na odbiorców w różnych grupach wiekowych. Tworzenie i koordynowanie szlaków kulinarnych jest przejawem przedsiębiorczości ich organizatorów.

\begin{abstract}
The aim of the elaboration is to show the role in the educational process of tourists that the culinary trails play, both the ones existing naturally in the anthropogenic space, and the ones set by the tourism organizers. The culinary trails give the tourists the possibility to directly associate with the knowledge on the selected culinary products. They also create the conditions to actively participate and acquire the skills of using different tools, as well as shape the social competences through the personal contact with individual persons and societies creating food. The elaboration pays special attention to the role of direct cognition and observation, and participation in the events taking place on the culinary trail. It points out the connection between the education with tourism and brings out the place of the culinary trails in the education tourism. It also includes an analysis of which elements of the trails influence the recipients in different age groups education-wise and how. The creation and coordination of the culinary trails is a sign of their organizers' entrepreneurship.
\end{abstract}

Słowa kluczowe: edukacja; szlak; turystyka; turystyka kulinarna

Keywords: culinary tourism; education; tourism; trail

Otrzymano: 6 listopada 2015

Received: 6 November 2015

Zaakceptowano: 5 marca 2016

Accepted: 5 March 2016 


\section{Sugerowana cytacja/Suggested citation:}

Dominik, P. (2016). Edukacyjna rola szlaków kulinarnych. Przedsiębiorczość - Edukacja, 12, 282-297.

Wstęp

Edukacja w najszerszym tego słowa znaczeniu jest to rozwój intelektualnych, etycznych, fizycznych i praktycznych zdolności człowieka. Rozwój ten określony jest przez lepsze rozumienie siebie i relacji ze światem, skuteczniejszą kontrolę własnych zachowań i większe sprawstwo wobec procesów zewnętrznych. $Z$ antropologicznego punktu widzenia człowiek jest nie tylko uzdolniony do edukacji, ale wręcz jej potrzebuje. Człowiek uczy się przez całe życie - nie jest to frazes, lecz stwierdzenie mające uzasadnienie w praktyce.

Edukacja to ogół czynności, procesów, mających na celu przekazywanie wiedzy, kształtowanie określonych cech i umiejętności (Doroszewski, 1996). Człowiek może zdobywać wiedzę, umiejętności i kompetencje społeczne przy wykorzystaniu różnych form oraz metod edukacyjnych, wśród których określone miejsce zajmuje turystyka, jej różne formy i narzędzia.

Celem niniejszego artykułu jest wskazanie roli, jaką w procesie edukacji turystów odgrywają szlaki kulinarne, czyli te szlaki, które ukształtowane zostały na przestrzeni wieków wskutek długotrwałych działań człowieka czy też występowania na danym obszarze określonych dóbr kulinarnych, które w sposób naturalny występują w przestrzeni antropogenicznej. Drugą grupę stanowią te szlaki, które zostały wyznaczone dla potrzeb turystyki i składają się z szeregu różnych komponentów. Szlak kulinarny ma charakter multiwytwarzalny, ze względu na mnogość elementów wchodzących w jego skład oraz będących nośnikiem treści szlaku. Są nimi: produkty kulinarne, miejsca ich wytwarzania, ludzie zaangażowani przy produkcji i prezentacji tychże produktów. Na szlaku kulinarnym powinny się znaleźć także obiekty noclegowe, odbywające się imprezy, festyny związane z tematyką szlaku. Szlak to przede wszystkim droga, która sama w sobie powinna być nośnikiem wiedzy na temat miejsc, wśród których szlak został wyznaczony. Szlak kulinarny jako produkt rzeczywisty, realnie występujący, stwarza okazję bezpośredniego doświadczenia procesów technologicznych, elementów tradycji, poznania ludzi i ich kultury.

\section{Bezpośrednie doświadczenie jako forma edukacji}

Świadectwo osobiste miało zawsze znaczenie fundamentalne niezależne od dyscypliny, w której miało zastosowanie. Niezależnie też od posiadanej wiedzy na temat danego kraju czy kontynentu, świadectwo kogoś, kto był tam osobiście, kto na własne oczy coś widział i sam czegoś doświadczył, liczyło się szczególnie (Przecławski, 1997).

Według klasyfikacji dokonanej przez K. Przecławskiego wśród motywów, którymi kierują się ludzie wyjeżdzający w celach turystycznych, na szczególne miejsce zasługują motywy związane z pragnieniem udania się do określonego kraju lub miejscowości, a są nimi:

- motyw poznania przyrody,

- motyw poznania kultury,

- motyw poznania życia społecznego.

Typologia turystów obejmuje szereg ich grup, wśród których dwie są szczególnie nastawione na edukację: 
- turyści poznający świat - dążący do zwiedzania i poznawania,

- turyści uczący się, którzy podróżują w celu zdobywania nauki i podnoszenia swoich kwalifikacji i rozwijania zainteresowań (Przecławski, 1996).

Szlaki kulinarne stwarzają możliwość bezpośredniego obcowania turystów z wiedzą na temat wybranych produktów kulinarnych. Stwarzają także warunki do aktywnego uczestnictwa i zdobywania umiejętności posługiwania się rozmaitymi urządzeniami stosowanymi przy wyrobie dóbr kulinarnych, jak również kształtują kompetencje społeczne przez osobisty kontakt, zarówno z pojedynczymi osobami, jak również ze społecznościami wytwarzającymi żywność. Człowiek będący na szlaku kulinarnym wielozmysłowo poznaje zastaną rzeczywistość: podziwia wzrokiem, smakuje, wącha, dotyka, wykonuje czynności, zadaje pytania, słucha opowieści i przyswaja informacje.

Najwcześniej sformułowaną zasadą wskazującą na konieczność zdobywania wiedzy przez bezpośrednie poznawanie rzeczy i zjawisk jest zasada poglądowości, inaczej nazywana zasadą bezpośredniości. Jej funkcją jest ułatwienie zrozumienia i zapamiętywania. Zasada poglądowości wyraża się tezą „Od konkretu do abstrakcji”. Myląca nazwa zasady wywodzi się nie od poglądu, lecz oglądu, czyli wykorzystania zmysłu wzroku w procesie poznania. Nieadekwatność nazwy polega jednak głównie na tym, iż zasada ta respektuje prawidłowość skuteczności procesu kształcenia związaną z wielozmysłowością, polisensorycznością bezpośredniego uczenia się. Zasada poglądowości akcentuje wielozmysłowy kontakt z poznawaną rzeczywistością. Powoduje ona powstawanie w świadomości człowieka zmysłowego obrazu zjawisk w postaci spostrzeżeń i wyobrażeń, na który składają się wrażenia wzrokowe, węchowe, smakowe i dotykowe.

Zasadę poglądowości dla dydaktyki sformułował J.A. Komeński, a następnie J.H. Pestalozzi. Działanie na konkretach, poznawanie ich wszystkimi zmysłami umożliwia stopniowe procesy uogólnienia i interioryzacji poznawanych pojęć. Droga kształcenia wiedzie od konkretu i działania na przedmiotach (czyli poznania bezpośredniego), przez wprowadzenie reprezentacji graficznej ikonicznej ${ }^{1}$ (czyli poznania pośredniego), do abstrakcyjnego poznania myślowego. Droga „od konkretu do abstrakcji” i w drugą stronę „od abstrakcji do konkretu” towarzyszy procesowi uczenia się niezależnie od wieku rozwojowego.

Jak napisał J.A. Komeński, „Niech to złotą zasadą będzie dla uczących, ażeby co tylko mogą, udostępniali zmysłom, a więc: rzeczy widzialne wzrokowi, słyszalne słuchowi, zapachy węchowi, rzeczy smak mające smakowi, namacalne dotykowi, a jeśli coś jest uchwytne dla kilku zmysłów, należy je kilku zmysłom naraz udostępnić” (1956: 75). Dużą rolę odgrywa również poglądowość, zwykle w formie pokazu odpowiednich czynności, gdyż ułatwia zrozumienie istoty i sposobu wykonania czynności przy nauczaniu działania, a tym samym przyspiesza ich opanowanie.

Poglądowość jest drogą umożliwiającą naukowe poznanie samej rzeczywistości - przez aktywne spostrzeganie. Nie jest to ostateczny warunek poznania, taka poglądowość może co najwyżej gwarantować należyte poznanie zmysłowe, z którym dopiero musi się wiązać poznanie umysłowe. Poglądowość może występować w procesie dydaktycznym w dwojakiej postaci. Najczęściej stosuje się poglądowość ilustratywną, przeważnie w podającym toku nauczania przez kojarzenie rzeczy i słów. Większą wartość dydaktyczną ma poglądowość operatywna, czynna, która nie ogranicza się do pokazu, lecz opiera się na działaniu samych uczestników pokazu. Występuje ona wówczas, gdy uczestnicy zamiast oglądać rzeczy, modele, eksperymenty

\footnotetext{
${ }^{1}$ Przykładowo: mapy szlaków kulinarnych.
} 
itp. sami je wykonują, sami gromadzą niezbędne zbiory, prowadzą obserwacje itd. Tak więc najlepsze wyniki daje realizowanie zasady poglądowości przez wiązanie obserwacji z oddziaływaniem na poznawany przedmiot, przez czynny kontakt uczestnika z przedmiotem. Druga funkcja zasady poglądowości w nauczaniu polega na ułatwianiu zrozumienia i zapamiętywania wyników myśli naukowej, uogólnień, praw itd. przez graficzne lub innego rodzaju symboliczne przedstawienia abstrakcji. Jest to funkcja symbolizująca.

Podstawowym elementem realizacji zasady poglądowości i istotną zasadą podczas poznawania szlaków kulinarnych jest stworzenie uczestnikom warunków do obserwacji. Aby w pełni wykorzystać walory poznawcze obserwacji, winna ona spełniać następujące warunki:

- uczestnicy muszą być nastawieni na obserwowanie określonego zjawiska przez podanie celu, zadań jak też planu prowadzenia obserwacji,

- obserwacja powinna być wnikliwa, wyczerpująca i zmierzająca do odkrycia związków i zależności między zjawiskami,

- wyniki obserwacji są lepsze, gdy uczestnicy prowadzą odpowiednie notatki z obserwacji. Strategia odkrywania pozwala na kształtowanie się człowieka innowacyjnego. Mówiąc innymi słowy, jest ona ukierunkowana na wzmacnianie predyspozycji badawczych, uzdolnień naukowych i myślenia twórczego oraz samodzielnego spostrzegania, poszukiwania, odkrywania i rozwiązywania problemów (Erasmus, 2006).

\section{Turystyka edukacyjna a szlaki kulinarne}

Organizowanie wycieczek szlakami kulinarnymi bądź do miejsc będących ich składowymi jest elementem turystyki edukacyjnej. Turystyka edukacyjna ze szczególnym wzmocnieniem stwarza okazję do zdobywania wiedzy, umiejętności i kompetencji społecznych.

Jest formą, która spełnia oczekiwania i potrzeby określonych grup turystów, kierujących się motywami poznawczymi i chęcią edukowania się podczas wyjazdów czy pobytów turystycznych. Ta forma edukacji sprzyja bowiem kształtowaniu się postaw transgresyjnych jednostki, dzięki czemu człowiek może uczyć się holistycznego spostrzegania i interpretowania rzeczywistości społecznej, kulturowej i wychowawczej. Turystyka edukacyjna w szczególny sposób sprzyja transgresji intelektualno-emocjonalnej zarówno dorosłych jej uczestników, jak i dzieci oraz młodzieży, przejawiając się w odrzucaniu zdezaktualizowanych pojęć i kategorii oraz przyjmowaniu nowych terminów adekwatnych do poznawanej rzeczywistości.

Transgresyjny charakter doświadczeń turystycznych nadal wymaga wnikliwych badań i refleksji przedstawicieli nauk humanistycznych. Pierwszą próbę tego typu podjął w swoich pracach L. Turos, u którego czytamy: „Można bowiem stwierdzić, że turystyka ze swojej istoty jest pewną formą transgresji, gdyż polega przecież na ciągłej zmianie miejsca i pobytu i kontakcie z coraz to innymi ludźmi, obiektami kultury, cywilizacji i przyrody" (2003: 46-50). Turos wymienia następujące korzyści ze stosowania turystyki jako systemu dydaktycznego:

- korzystanie z różnych atrakcyjnych źródeł wiedzy (informacje przekazane przez przewodników i pilotów wycieczek, przewodniki drukowane, informatory, opracowania monograficzne),

- łączenie indywidualnych aspiracji edukacyjnych z programem wycieczki,

- tworzenie warunków do konfrontacji wiedzy teoretycznej z praktyką,

- przyczynianie się do pogłębienia motywacji samokształceniowej uczestników,

- potęgowanie atrakcyjności wiadomości i doświadczeń poznawczych uzyskanych na wycieczce. 
Rola edukacyjna szlaków kulinarnych uwidacznia się w dużej mierze w edukacji osób dorosłych, rodzin wielopokoleniowych czy też rozmaitych grup społecznych. Eksponując nowe tereny i składowe szlaków kulinarnych, ludzie doświadczają samokształcenia. W tym kontekście turystyka oparta na poznaniu szlaków kulinarnych jest postrzegana jako narzędzie rozwijające osobowość człowieka. Turystyka edukacyjna sprzyja samokształceniu, które sprowadza się do tego, że wycieczki skłaniają uczestników do traktowania podróży jako przygody intelektualnej. Jednocześnie podróże skłaniają do uczenia się określonych wzorów przeżywania, myślenia i zachowania społecznego.

\section{Edukacja kulturalna}

Szlaki kulinarne odgrywają również rolę w szeroko rozumianej edukacji kulturalnej. Wyróżnia się trzy zakresy pojmowania edukacji kulturalnej. Najbardziej ogólny to edukacja humanistyczna. Takie rozumienie edukacji jest pochodną szerokiego rozumienia kultury. Edukacja kulturalna w tym sensie jest wprowadzaniem w kulturę zastaną, rozumianą antropologicznie, czyli w różne systemy wiedzy i praktyki społecznej. Przyjmowanie norm zachowań, wytworów, postaw - to kultura normatywna. Antropolog patrzy na kulturę m.in. przez takie wytwory, jak: wałek do ciasta, dzieża do mąki czy też maselnica lub kierznia. Ludzie na różnym poziomie rozwoju kulturalnego wytwarzają różne przedmioty. Im bardziej rozwinięta kultura, tym bardziej są one wyrafinowane (Richards, 2007).

Nieco węższe rozumienie edukacji kulturalnej to edukacja do kultury symbolicznej, fragmentu ludzkich zachowań przejawiających się w użyciu znaków konwencjonalnych, czyli symboli, których przeznaczenie nie ma charakteru instrumentalnego. Kultura symboliczna wypełnia obszar duchowy, świadomościowy, w którym człowiek zaczyna interpretować, rozumować, zastanawiać się i przeżywać. W kulturze tej mieszczą się wytwory artystyczne, religia, nauka, literatura, muzyka i plastyka.

Składowe szlaków kulinarnych, ze względu na swoją różnorodność, wypełniają trzy zakresy edukacji kulturowej, są obecne w systemach wiedzy i praktyki społecznej, tworzą produkty materialne, ale także związane są z symboliką, obrzędowością, wierzeniami czy estetyką.

Funkcja kulturotwórcza poznawania szlaków kulinarnych realizowana jest w ujęciu socjologicznym jako spotkanie kultur społeczności odwiedzającej i przyjmującej, współczesnej i ówczesnej. Znajomość kultury innych regionów, poznawanej podczas wędrowania szlakami kulinarnymi, może przyczynić się do wzbogacenia własnego systemu wartości turysty, który może go przekazać innym, oraz może sprzyjać rozwojowi jego kultury osobistej (Lubański, 2006).

\section{Walory poznawcze szlaków kulinarnych}

Szlaki kulinarne stanowią jeden z głównych motywów leżących u podstaw wyjazdów kulinarnych turystów, którzy chcą poznawać w warunkach naturalnych produkty kulinarne, miejsca ich pochodzenia i wytwarzania, ludzi, z którymi są związane, oraz zdobywać wiedzę na temat historii, tradycji i współczesności tychże kulinariów.

W poznawaniu tych szlaków ważne są m.in. tempo zwiedzania, przekazanie najbardziej istotnych informacji o oglądanym obiekcie oraz wzbudzenie zaciekawienia. Zbyt duże tempo realizacji programu szlaku kulinarnego, brak selekcji treści programowych oraz 
powierzchowność przekazywanych wiadomości sprawiają, że szansa edukacyjna nie jest w pełni wykorzystana (Lubański, 2006).

Rola edukacyjna szlaków kulinarnych związana jest $\mathrm{z}$ osobistym poznawaniem przez turystów produktów i potraw danego regionu oraz tradycji ich przygotowania, odwiedzaniem lokali gastronomicznych, winiarni, miejscowych targów, a także udziałem w festynach czy imprezach kulinarnych. Szlaki te wraz z produktami uzupełniającymi, spełniającymi ważną funkcję promocyjną, pozwalają na poszerzenie wiedzy turystów oraz na zwiększenie atrakcyjności turystycznej regionu. Nie do przecenienia jest funkcja edukacyjna szlaków - tematyka kulinarna może również łączyć pokolenia.

Szlaki kulinarne stają się coraz bardziej popularne w Polsce. Są częścią szeroko rozumianej turystyki kulturowej. Mogą być ważnym czynnikiem rozwoju lokalnego czy regionalnego. Podążanie określonymi szlakami stanowi jeden z powodów skłaniających turystów do udziału w podróżach kulinarnych. Szlaki mają na celu wypromowanie walorów turystycznych, w tym przyrodniczych i antropogenicznych, a zwłaszcza regionalnych tradycji kulinarnych oraz lokalnych produktów żywnościowych (Woźniczko, Orłowski, 2014).

Wyróżnia się cztery grupy istotnych komponentów składających się na szlak kulinarny:

- atrakcje pierwotnie stworzone nie dla celów turystycznych - zatem obiekty oryginalne, stanowiące właściwe nośniki wartości kulturowych (zamki, świątynie, zabytkowe centra miast, dawne obiekty techniki itd.),

- atrakcje stworzone dla celów turystycznych (muzea, eventy, parki tematyczne itd.),

- miejsca usług dla turystów (obiekty noclegowe, restauracje, sklepy z pamiątkami, wypożyczalnie samochodów i rowerów, amfiteatry itd.),

- instytucje, organizacje i stowarzyszenia powołane w celach obsługi szlaku lub wykonujące tę działalność obok innych swoich czynności (Rohrscheidt, 2010).

Szlaki kulinarne, należące do szlaków kulturowo-turystycznych, oferują turystom indywidualnym możliwość względnie bezpiecznego podróżowania w znanym i opisanym, najczęściej także dla ich potrzeb fizycznie oznaczonym, obszarze (Puczko, Ratz, 2006). Funkcjonujące $\mathrm{w}$ ramach dobrze zorganizowanych systemów trasy, moduły, opcje i pakiety oraz usługowa działalność koordynatorów i punktów informacyjnych ułatwiają im sprawne planowanie i realizację ich indywidualnych podróży.

Współczesny szlak kulinarny powstaje niemal zawsze jako sposób urzeczywistnienia określonego tematu lub grupy tematów, wychodzących naprzeciw zainteresowaniom turystów. Zwiększa to atrakcyjność podróży turystycznych odbywanych w ramach konkretnej destynacji i ułatwia ich organizatorom zdobycie nowej grupy klientów.

Szlak tematyczny stanowi także ukonkretnienie oferty turystyczno-kulturowej danego obszaru, umożliwia stworzenie w jego ramach nowej marki turystycznej dla zespołu miejsc i obiektów (Rohrscheidt, 2010).

Szczególną formą podróży o charakterze edukacyjnym jest podróż studyjna, czyli ukierunkowany tematycznie, wielodniowy wyjazd o charakterze kulturowo-edukacyjnym, w którym niewielka grupa turystów pod kierunkiem wykwalifikowanego specjalisty lub przewodnika zwiedza region, kraj lub szlak kulinarny. Cechą takiej podróży jest dążenie do przekazania wielostronnej wiedzy z danego tematu i o danym regionie, szerszej niż w wypadku typowych imprez turystycznych. Podróże tematyczne natomiast to zaplanowane wyjazdy turystyczne, których program koncentruje się wokół jednego wiodącego tematu związanego z szeroko rozumianą kulturą. Istotny jest w nich kontekst edukacyjny, związany z charakterem wyjazdu. Uczestnicy takich podróży nastawieni są na uzyskanie pogłębionej wiedzy w danej tematyce. 
W programie tematycznych podróży znajdziemy formy wykładu realizowane in situ, spotkania $\mathrm{z}$ fachowcami lub pasjonatami $\mathrm{w}$ danej dziedzinie, imprezy kulturalne lub naukowe seminaria. Osobom prowadzącym takie wyjazdy: przewodnikom turystycznym czy pilotom wycieczek stawiane są wysokie wymagania (Kruczek, 2013).

Tworzenie szlaków kulinarnych o przewodniej tematyce pozwala łączyć obiekty i miejscowości w pewien logiczny temat, będący podstawą kreowania nowego produktu turystycznego. Potrzeba poszukiwania nowych tematów i atrakcji turystycznych stanowi wyzwanie dla organizatorów turystyki i lokalnych samorządów do tworzenia koncepcji oraz wdrażania pomysłów na nowe trasy turystyczne (Kruczek, 2011).

\section{Szlaki kulinarne w Polsce}

W chwili obecnej w Polsce funkcjonuje ok. 23 szlaków kulinarnych. Oprócz nich Polska ma także wiele miejsc i lokalnych atrakcji, które mogą być uznane jako zalążek szlaków kulinarnych. Mają one szansę przekształcić się w znane, renomowane, rekomendowane i chętnie odwiedzane miejsca. Jednak aby tak się stało, musi być spełnione minimum warunków organizacyjnych. By szlaki funkcjonowały bezkolizyjnie i spełniały swoją funkcję edukacyjną potrzebne są: pełne zaangażowanie właścicieli i zarządców, współpraca z lokalnym samorządem oraz przedsiębiorcami, stałe podnoszenie jakości świadczonych usług zgodnie $\mathrm{z}$ wymogami i oczekiwaniami turystów, bycie krok do przodu w stosunku do oczekiwań turystów, wykorzystanie wiedzy i doświadczenia najlepszych, poszukiwanie nowych możliwości rozwoju, korzystanie $\mathrm{z}$ dostępnych funduszy pomocowych.

Największe szanse w dziedzinie rozwoju szlaków kulinarnych mają tak zwane silne regiony kulturowe o wyraziście wyodrębnionej tradycji i sferze kultury życia codziennego, w tym także odrębnej i oryginalnej kuchni regionalnej, takie jak: Podhale, Kaszuby, Żywiecczyzna ale także Podlasie ze swoją historyczną mieszanką kuchni polsko-litewsko-rusko-tatarskiej.

Najstarsze szlaki kulinarne to Małopolski Szlak Owocowy, Szlak Oscypkowy, Szlak „Małopolska pachnąca ziołami”, Lubuski Szlak Miodu i Wina czy Sandomierski Szlak Jabłkowy. W miastach tworzone są miejskie szlaki kulinarne oparte na lokalnych restauracjach. Istnieją również szlaki, które nie są typowymi szlakami kulinarnymi, ale ze względu na swój wyjątkowy charakter warto o nich wspomnieć. Takim szlakiem jest szlak tatarski, który głównie przybliża kulturę tatarów, a przy okazji podążania nim można zasmakować wielu potraw z kuchni tatarskiej.

Zwiedzając polskie szlaki kulinarne, turyści mają okazję poznawać lokalne restauracje, a w nich spożywać potrawy tradycyjne dla danego regionu. Do takich szlaków należą:

- szlak kulinarny „Śląskie Smaki”, który obejmuje ponad 35 certyfikowanych restauracji, czasami nawet małych, ale oferujących lokalne potrawy. Większość położona jest w pobliżu atrakcji turystycznych;

- szlak kulinarny „Podkarpackie Smaki”, promujący region podkarpacki jako obszar o bogatym dziedzictwie kulturowym oraz kulinarnym. Obejmuje on liczne restauracje, karczmy i certyfikowane gospodarstwa agroturystyczne proponujące tradycyjne potrawy i produkty;

- Gęsinowy Szlak Kulinarny, powstały w ramach projektu Kujawsko-Pomorskiej Organizacji Turystycznej. Odpowiednie certyfikaty otrzymało tu 17 restauracji z regionu, oferujących potrawy z gęsiego mięsa. 
Według podobnych koncepcji powstały i są tworzone produkty turystyki kulinarnej w niektórych miastach, na przykład:

- Szlak Kulinarny Centrum Gdyni - pierwszy tego typu szlak w Polsce,

- Białostocki Szlak Kulinarny - powstał jako jeden z pierwszych, uwzględnia wielokulturowy charakter miasta oraz regionu, co znajduje odbicie w bogactwie tradycyjnej kuchni podlaskiej. Szlak obejmuje ponad 30 restauracji, zlokalizowanych głównie w centrum miasta.

Edukacja przez poznawanie szlaków kulinarnych dotyczyć może upraw, hodowli i produktów powstających z lokalnie otrzymywanych surowców.

Warto zwrócić uwagę na Małopolski Szlak Owocowy przebiegający przez 23 gminy i obejmujący około 300 gospodarstw, w których rosną sady. Osoby zainteresowane procesem sadzenia drzew, pielęgnacji owoców oraz produkowania przetworów otrzymają na ten temat obszerne informacje, możliwa jest też degustacja różnych owoców.

Także w Małopolsce powstał Szlak Oscypkowy, który obejmuje około 30 bacówek na obszarze 6 powiatów województwa małopolskiego (najwięcej jest ich w powiatach: tatrzańskim, nowotarskim, żywieckim). Poza elementami edukacyjnymi związanymi z wytwarzaniem oscypków i ich degustacją, ważnym elementem poznawania szlaku jest możliwość zetknięcia się z lokalną historią, dziejami rodów bacowskich, obejrzenie obiektów tradycyjnego budownictwa drewnianego i posłuchania gawęd góralskich.

Lubuski Szlak Wina i Miodu to przykład utworzenia produktu turystycznego (w formie szlaku kulinarnego), opartego na potencjale regionu związanym $\mathrm{z}$ takimi produktami regionalnymi, jak: wino, miód pitny i miód pszczeli, które zostały wpisane na listę produktów tradycyjnych. Na szlaku znajduje się ponad 20 miejsc i obiektów, o których historii dowiadują się turyści podczas zwiedzania (Wysokińska, 2014).

M. Woźniczko i D. Orłowski (2011) podzielili szlaki kulinarne funkcjonujące w Polsce na 4 grupy:

1. szlaki miejskie, prowadzące do lokali gastronomicznych (np. restauracji, pubów) oferujących kuchnie lokalne, regionalne i narodowe (np. Kulinarny Szlak Turystyczny „Kuchnia Polska”, Szlak Kulinarny „Centrum Gdyni”, Białostocki Szlak Kulinarny, Kulinarny Poznań),

2. szlaki z motywem przewodnim: wino i miód (np. Lubuski Szlak Wina i Miodu², Małopolska Ścieżka Winna, Podkarpacki Szlak Winnic, Agroturystyczny Szlak Winno-Miodowy „Grodziec”),

3. szlaki tematyczne, promujące lokalne, regionalne lub tradycyjne produkty żywnościowe (np. Małopolski Szlak Wód Mineralnych, Małopolski Szlak Owocowy, Sandomierski Szlak Jabłkowy, Szlak Oscypkowy ${ }^{3}$, Szlak „Fasolowa Dolina”, Małopolska Wieś Pachnąca Ziołami),

4. szlaki promujące potrawy lokalne, regionalne lub tradycyjne (np. Szlak Kulinarny „Leśnymi Smakami”, Szlak Jadła Przygranicza (Mazurskiego), Szlak Specjalności Kuchni Kwater Wiejskich, Podlaski Szlak Tatarski).

W Polsce szlaki kulinarne jako produkt turystyczny stanowią jeszcze swoistą niszę rynkową, dlatego też należy rozwijać i udoskonalać już istniejące szlaki poświęcone dziedzictwu kulinarnemu oraz tworzyć nowe. Tego rodzaju inicjatywy, które będą wykorzystywały już istniejące atrakcje turystyczne oraz tworzyły nowe, bez wątpienia spowodują wzrost atrakcyjności

\footnotetext{
${ }^{2}$ Więcej o szlaku w: Woźniczko, Orłowski (2011b).

${ }^{3}$ Więcej informacji w: Woźniczko, Orłowski (2009).
} 
turystycznej regionu, a to z kolei skutkowało będzie rozwojem ekonomiczno-społecznym danego obszaru (Woźniczko, Orłowski, 2014).

Szlak kulinarny to nie tylko oznakowana trasa i tematycznie dobrane obiekty. Jest to dość skomplikowany twór złożony z wielu, wzajemnie dopełniających się elementów. Turystom podróżującym po danym szlaku oferuje się różnorodne pojedyncze usługi (np. przewodnickie, gastronomiczne, noclegowe) i dobra materialne (np. przewodniki i mapy, pamiątki, produkty regionalne), także produkty bardziej złożone: lokalne pakiety turystyczne, wydarzenia związane $\mathrm{z}$ tematyką trasy (m.in. pokazy, prezentacje, festiwale, konkursy), kompleksowe zwiedzanie obiektów. Tak więc w przypadku szlaku kulinarnego powinno się zwrócić uwagę przede wszystkim na to, aby elementy, które on łączy, były spójne i układały się w jedną całość. Nie chodzi tu jednak o popadanie w monotematyczność, ale o dopasowanie atrakcji szlaku tak, by turysta był nimi zainteresowany i chętny do ich poznawania. Na szlaku kulinarnym mogą znaleźć się karczma regionalna oferująca regionalny obiad, atrakcyjny skansen lub pałac do zwiedzania i poznania jego historii, sklep z rękodziełem lub też atrakcje zapewniające czynną rekreację. Nocleg może być zaoferowany w hotelu, który serwuje wyśmienite śniadania przygotowywane na podstawie regionalnych receptur (Dominik, 2014).

Podstawowa oferta (opierająca się na przewodniej idei szlaku) powinna być obudowana usługami towarzyszącymi, wzbogacającymi i uatrakcyjniającymi pobyt na danym terenie (np. różnorodne propozycje biernego i czynnego wypoczynku, zwiedzania obiektów poza szlakiem, oferta kulturalna, usługi dopełniające (Milewska, Prączko, Stasiak, 2010).

\section{Aktywności wspomagające edukację na szlakach}

W przypadku szlaków kulinarnych lub turystycznych mamy do czynienia przeważnie $\mathrm{z}$ tematami lokalnymi, taki też charakter będą miały opowieści związane z lokalnymi atrakcjami, wydarzeniami historycznymi, ludźmi zasłużonymi dla miejscowych społeczności. Tak należy przedstawiać dzieje dawnych zakładów, tradycje historyczne obiektów gastronomicznych, dawnych receptur i przepisów, działalność osób związanych ze sztuką kulinarną. To inny aspekt historii - nie tej od wielkich wydarzeń, cennych zabytków, ale bliższej ludziom, mniej znanej, a może przez to równie ciekawej. Powinna temu towarzyszyć przekazywana wiedza dotycząca ziemi, upraw, właściwości artykułów żywnościowych i produktów miejscowego przetwórstwa, sposobów przetwarzania, dawnych sprzętów i urządzeń, związanych z tym obyczajów, warunków życia. To są informacje i opowieści związane z danym regionem, miejscem, tym cenniejsze, że nie występują we współczesnej infosferze.

Dobrze przygotowane i rozwijane szlaki kulinarne powinny mieć wkomponowane w swą strukturę atrakcyjne i rozbudowane elementy swoistej narracji, w której pojawią się zarówno elementy historyczne $\mathrm{w}$ różnych ujęciach, w tym tradycje kuchni, jak również prezentujące właściwości i szczególne cechy oferowanych dań, specjałów, przysmaków, wytwarzanych produktów tradycyjnych. Ta warstwa narracyjna wywodząca się po części ze współczesnego marketingu, musi mieć jednak formę jak najbardziej atrakcyjną, bliższą historycznej opowieści, również gawędzie osoby znającej wszelkie tajniki sztuki kulinarnej i obsługi gości. Takie opowiadanie jest formą dzielenia się - w tym przypadku dzielenia się osobistą wiedzą.

Istnieje wiele form aktywności, które pomagają w realizacji funkcji edukacyjnej szlaków kulinarnych i są uzależnione od indywidualnych zainteresowań poszczególnych turystów. Wśród nich wymienia się spotkanie z cenionym właścicielem restauracji lub szefem kuchni, który to potrafi swoim profesjonalizmem i interesującą osobowością pobudzić klienta do 
pogłębiania zainteresowań kulinariami czy też stać się źródłem wiedzy na tematy, które prezentuje.

Ciekawym przeżyciem jest udział w różnego typu konkursach gastronomicznych. Turyści mogą w jednym miejscu spotkać specjały kulinarne oraz ich twórców, jednocześnie usłyszeć o historii i pochodzeniu prezentowanych posiłków.

Poznawcze może być również uczestnictwo w imprezach otwarcia nowych restauracji. Imprezom tego typu towarzyszy promocja kuchni, która będzie w nich serwowana, a wydarzenia tego typu przechodzą do historii i stają się niezapomnianym przeżyciem. Szczególnie warte uwagi są inicjacje działalności karczm regionalnych, których otwarciu towarzyszą obrzędy ludowe.

Bardzo specyficzną okazją do poszerzania wiedzy kulinarnej jest poszukiwanie zwykłych obiektów gastronomicznych. To właśnie takie obiekty służące przede wszystkim miejscowej ludności kultywują najczęściej tradycje kulinarne. Na całym świecie istnieją zakątki, w których możemy skosztować potraw na codzień służących miejscowej ludności. Przykładem mogą być greckie tawerny położone w odległych częściach wysp Hellady czy też charakterystyczne dla tego kraju kafeniony (Boniface, 2003).

Edukacyjny może być także udział w gastronomicznych festynach. Na świecie znane są festyny, których tematem jest prezentacja potraw, produktów kulinarnych, regionalnych i tradycyjnych. Doskonałym przykładem jest bawarski Oktoberfest, podczas którego prezentują swoje wyroby browary Niemiec, natomiast na wydarzenie to ściągają turyści z Niemiec, całej Europy i świata. Także pomniejsze festyny stają się miłym wspomnieniem i okazją do budowania doświadczeń kulinarnych. W krajach niemieckojęzycznych są nimi święta uliczne bądź festyny związane z degustacją lokalnych win, wypieków czy wędlin.

Bardzo wyrafinowanym motywem wyjazdów kulinarnych jest poszukiwanie składników potraw. Celem wyjazdów tego typu stają się miejsca, z których pochodzą określone przyprawy, uprawiane są określone odmiany roślin bądź hodowane są zwierzęta, których mięso, mleko czy jaja są wykorzystywane w potrawach.

Istnieje też grupa turystów motywujących swoje wyjazdy kulinarne chęcią uczestnictwa w kursach gastronomicznych, których uczestnicy nie tylko są obserwatorami, ale też biorą czynny udział w przygotowaniu potraw związanych z tradycją regionalną (Kowalczyk, 2005).

W tabeli 1 zaprezentowano wybrane możliwości edukacyjne przykładowych szlaków kulinarnych.

\section{Rola edukacyjna Konsorcjum Produktowego „Polskie Szlaki Kulinarne”}

Konsorcjum Produktowe „Polskie Szlaki Kulinarne” zostało powołane przez Polską Organizację Turystyczną (POT). Jest ono dobrowolnym i nieformalnym zrzeszeniem podmiotów zajmujących się promocją tradycji kulinarnych oraz produktów regionalnych na podstawie walorów środowiska przyrodniczego, dziedzictwa kulinarnego i kulturowego własnego regionu. Działa ono samodzielnie w afiliacji przy Polskiej Organizacji Turystycznej jako partner POT bez prawa wyłączności.

Celem Konsorcjum jest:

- promocja kulinarnego produktu turystycznego opartego na kuchni regionalnej i produktach tradycyjnych w kraju i poza jego granicami, a także stworzenie kulinarnego wizerunku Polski jako mocnej, narodowej marki, 


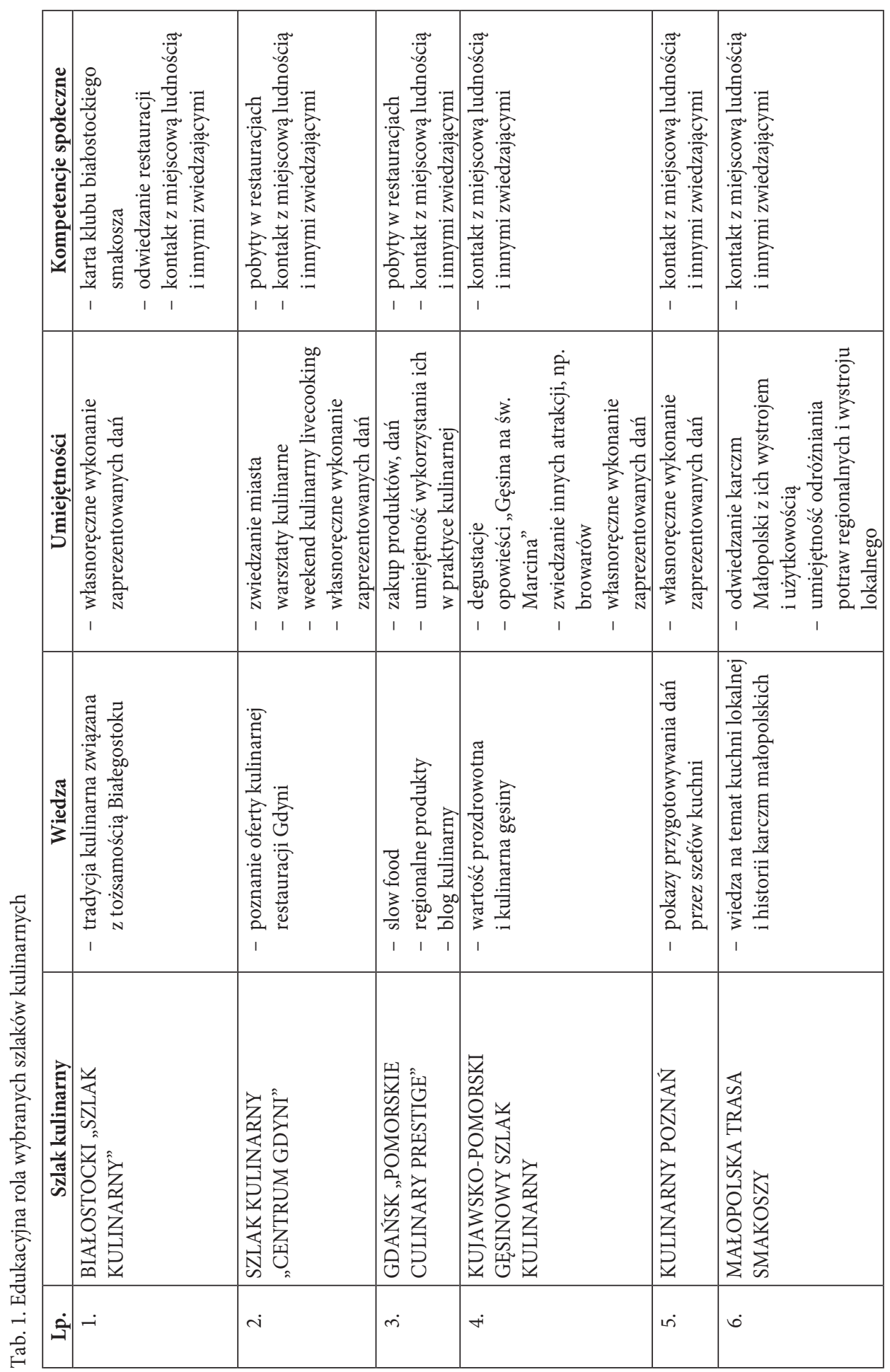




\begin{tabular}{|c|c|c|c|c|}
\hline 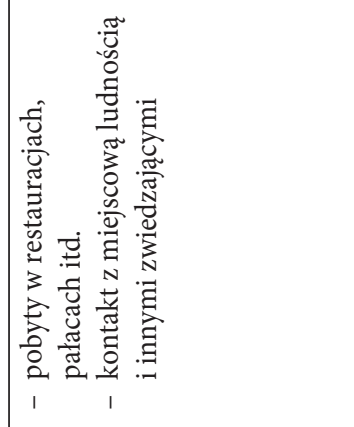 & 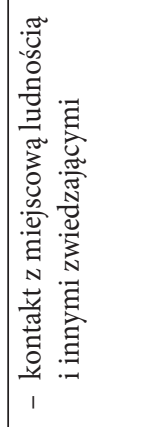 & 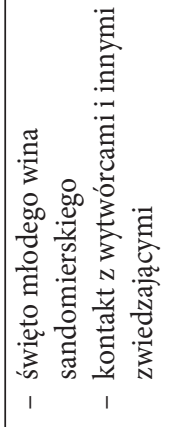 & 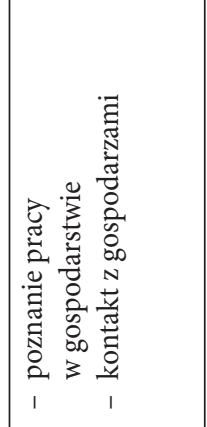 & 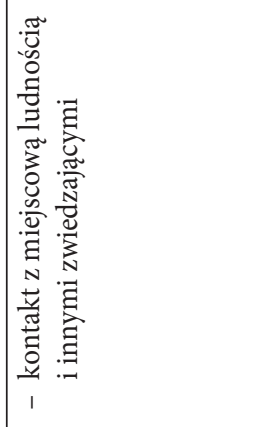 \\
\hline 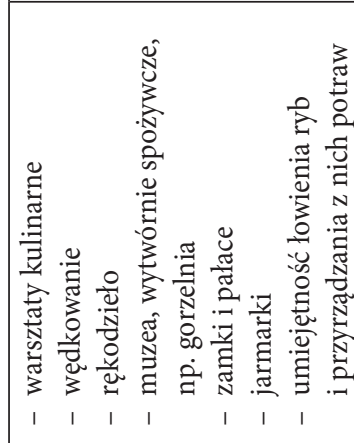 & 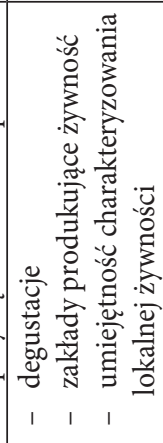 & 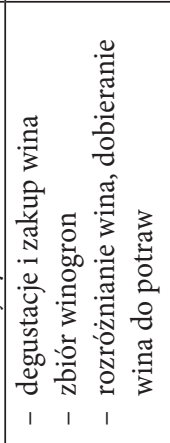 & 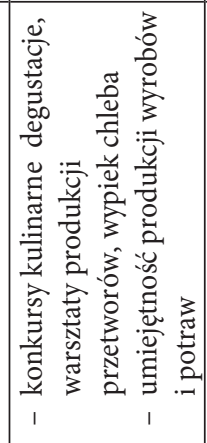 & 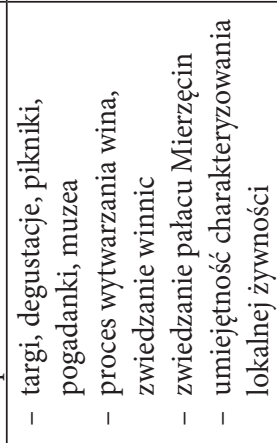 \\
\hline 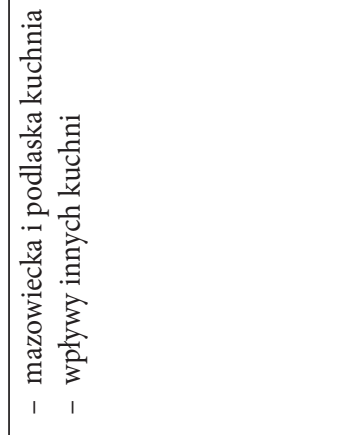 & 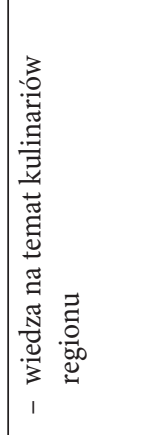 & 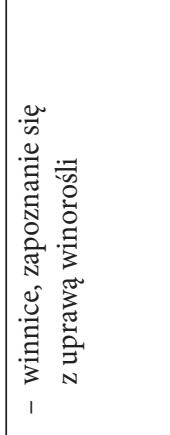 & 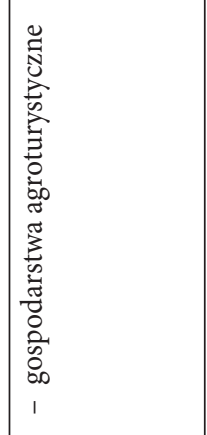 & 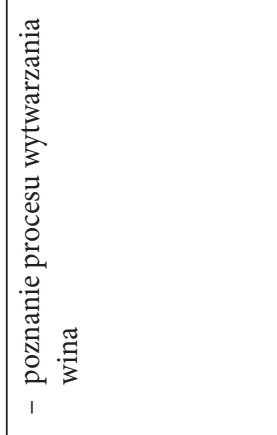 \\
\hline 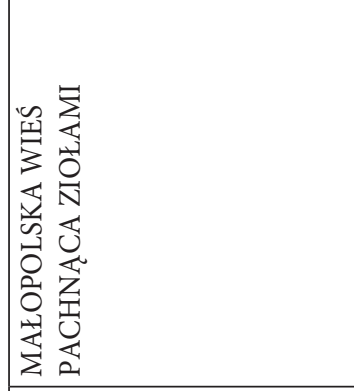 & 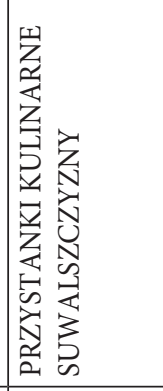 & 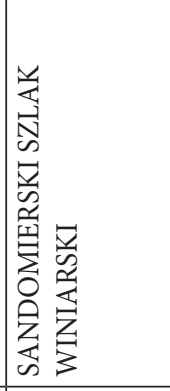 & 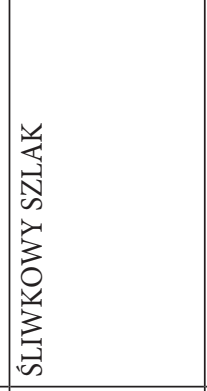 & 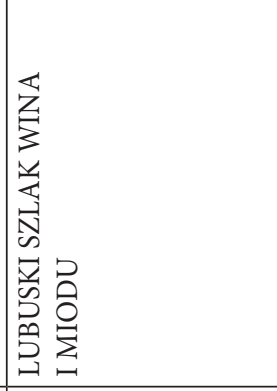 \\
\hline & $\infty$ & $\sigma^{\circ}$ & $\stackrel{0}{0}$ & $\dot{=}$ \\
\hline
\end{tabular}




\begin{tabular}{|c|c|c|c|c|}
\hline 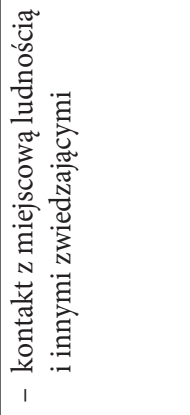 & 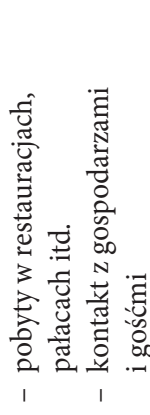 & 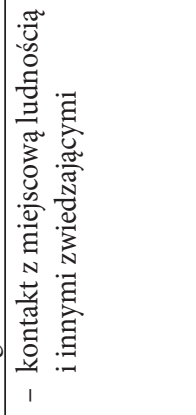 & 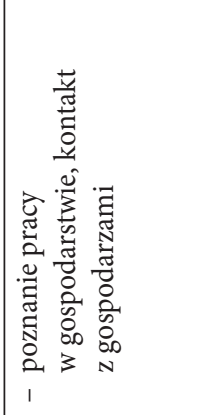 & 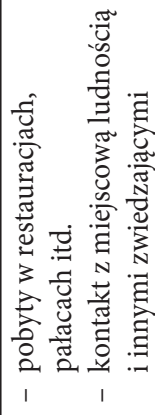 \\
\hline 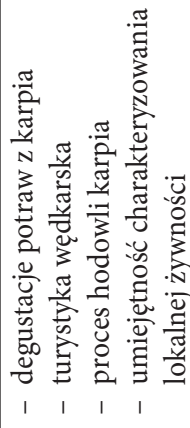 & 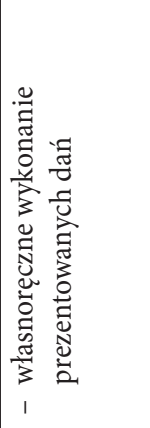 & 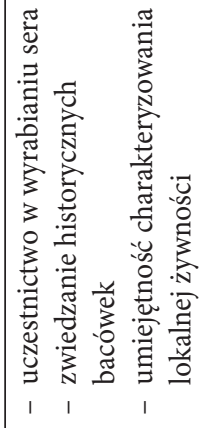 & 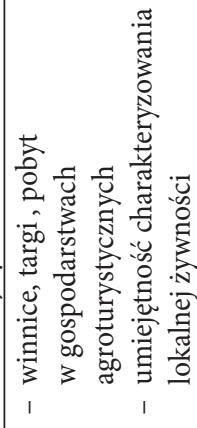 & 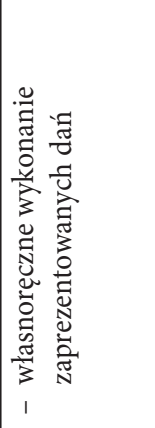 \\
\hline 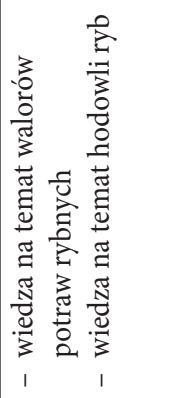 & 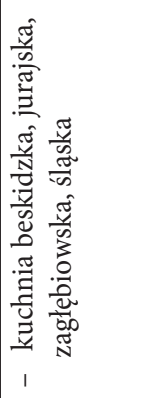 & 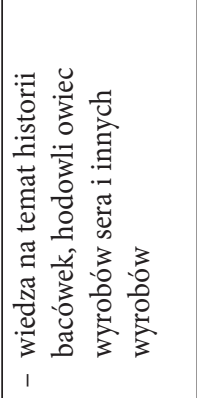 & 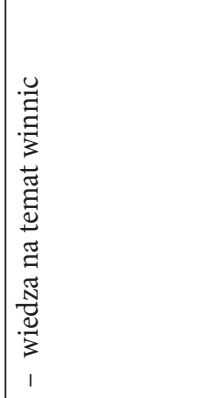 & 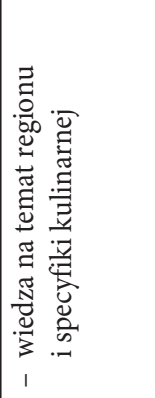 \\
\hline 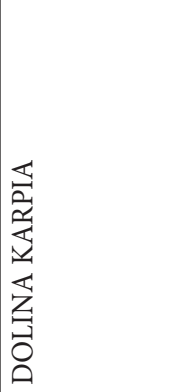 & 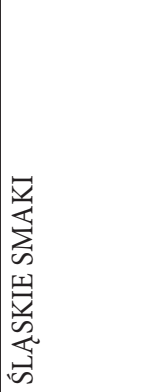 & 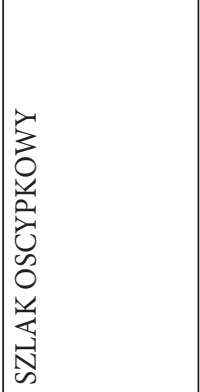 & 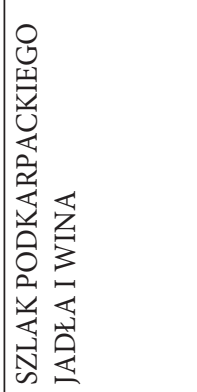 & 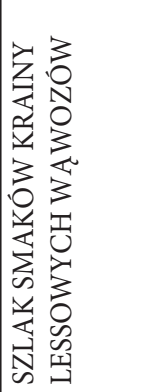 \\
\hline$\simeq$ & $\dot{2}$ & 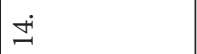 & $\stackrel{20}{2}$ & 10 \\
\hline
\end{tabular}

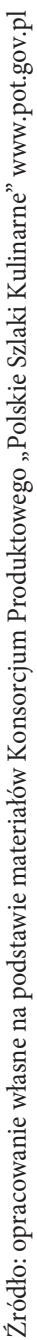


- podniesienie atrakcyjności turystycznej polskich regionów na podstawie walorów środowiska przyrodniczego i dziedzictwa kulturowego, w szczególności kulinarnego;

- spowodowanie wzrostu zainteresowania produktami tradycyjnymi i zwiększenie popytu na te produkty,

- działanie na rzecz podniesienia konkurencyjnej przewagi szlaków kulinarnych przez działanie w grupie.

Konsorcjum swe cele realizuje przez inicjowanie i podejmowanie wspólnych działań promocyjnych, edukacyjnych, szkoleniowych i eksperckich, wymianę doświadczeń, współpracę z władzami lokalnymi i samorządowymi, przedsiębiorcami, producentami, branżą gastronomiczną i turystyczną.

Do zadań Konsorcjum w szczególności należy:

- podejmowanie wspólnych działań promocyjnych, obejmujących m.in.: publikacje, multimedia, materiały radiowe i telewizyjne, stronę internetową, podróże studyjne, konferencje, warsztaty, targi turystyczne, festiwale kulinarne i inne tego typu wydarzenia o charakterze promocyjnym,

- stymulowanie powstawania zintegrowanych kulinarnych produktów turystycznych opartych na kuchni regionalnej i produktach tradycyjnych oraz wzbogacanie tych produktów o nowe elementy w celu uzyskania efektów komplementarności,

- wzajemny transfer wiedzy, budowa marki, w tym korzystanie z doświadczeń zagranicznych,

- organizacja szkoleń, których celem jest podnoszenie jakości usług, komercjalizacja oferowanego produktu turystycznego, implementacja dobrych praktyk.

\section{Podsumowanie}

Wiedza, umiejętności i kompetencje społeczne to efekty kształcenia, które powinny zwieńczać dzieło edukacyjne. Wszystkie to osiągnięte w naturalnym środowisku występowania przedmiotu zainteresowań, w bezpośrednim kontakcie z przyrodą, ludźmi i różnego rodzaju obiektami jest bez porównania pełniejsze, głębsze i trwalsze niż wiadomości uzyskane podczas lektury literatury czy też słuchania opowieści osób trzecich. Osobiste doświadczenia wyniesione z podróżowania szlakami kulinarnymi ma wielką wartość ze względu na bezpośredniość kontaktu. Duże znaczenie edukacyjne ma rozbudzenie zainteresowań zarówno dorosłych uczestników, jak i dzieci oraz młodzieży, co wiąże się ściśle z uczestnictwem w wycieczce. Staje się ono zasadniczym motywem poznania. Dzięki temu gromadzenie wiedzy następuje w sposób ciekawy i niebanalny, a także rozwija się spostrzegawczość i wyobraźnia uczestników.

Istnieje duży potencjał do wykorzystania właśnie w zakresie poznawania szlaków kulinarnych. Wieloelementowość szlaków sprawia, że turyści poznają główny produkt kulinarny, a niejako przy okazji edukują się w różnych zakresach. Edukacyjna rola szlaków kulinarnych jest zatem nie do przecenienia.

Literatura

References

Boniface, P. (2003). Tasting Tourism: Travelling for food and drink. Priscille Boniface, Ashgeste Publishing Limited, Hampshire. 
Dominik, P. (2014). Szlak kulinarny jako produkt turystyczny. W: P. Dominik, (red.) Szlaki kulinarne jako element turystycznej atrakcyjności regionu Mazowsze. Warszawa: Oficyna Wydawnicza ASPRA-JR, 11-13.

Doroszewski, W. (1996). Stownik języka polskiego, Warszawa: PWN.

Drążkiewicz, J. (2015, 15 czerwca). Edukacyjne funkcje turystyki. Pozyskano z www.wycieczkiznami.pl.

Erasmus, E. (2006). Strategie uczenia się i studiowania w gospodarce rynkowej. ZN Almamer, Wyższa Szkoła Ekonomiczna, 3(43), 166.

Komeński, J.,A. (1956). Wielka dydaktyka, Wrocław: Ossolineum.

Kowalczyk, A. (2005). Turystyka kulinarna - ujęcie geograficzne, UW, Turyzm 15, 163-168.

Kruczek, Z. (2011). Szlak oscypkowy w Małopolsce. Droga od pomysłu do produktu turystycznego. W: B. Włodarczyk, B. Krakowiak, J. Latosińska (red.), Kultura i turystyka. Wspólna droga, Łódź: Uniwersytet Łódzki, Instytut Geografii Miast i Turyzmu.

Kruczek, Z. (2013). Znaczenie szlaków kulturowych dla rozwoju turystyki edukacyjnej. W: A. Rapacz, Gospodarka turystyczna w regionie. Wrocław: Prace naukowe UE we Wrocławiu, 304, 124-126.

Lubański, K. (2006). Pedagogiczny potencjał turystyki. ZN Almamer Wyższa Szkoła Ekonomiczna, 3(43). Milewska, M., Prączko, A., Stasiak, A. (2010). Podstawy gastronomii. Warszawa: PWE.

Przecławski, K. (1996). Człowiek a turystyka. Zarys socjologii turystyki. Kraków: Albis.

Przecławski, K. (1997). Turystyka a kultura na przełomie XX/XI wieku. Kulturowe aspekty turystyki i gospodarki turystycznej. Warszawa: PST, 13.

Puczko, L., Ratz, T. (2006). Trailing Goethe, Humbert, and Ulysses. Cultural Routes in Tourism. W: A. Stasiak, Produkt turystyczny - szlak, Turystyka i Hotelarstwo, 10, 9-40.

Rapacz, A. (2013). Gospodarka turystyczna w regionie. Prace naukowe UE we Wrocławiu, 304, 124.

Richards, G. (red.) (2007). Cultural tourism. Global and Local perspectives. New York: The Haworth Hospitality, Press, 131-148.

Rohrscheidt, A.M. (2010). Regionalne szlaki tematyczne. Idea, potencjał, organizacja. Kraków: Proksenia.

Turos, L. (2003). Turystyka edukacyjna i transgresja, Warszawa: Ypsilon.

Turos, L. (2001). Wprowadzenie do wiedzy o turystyce edukacyjnej, Warszawa: Ypsilon.

Woźniczko, M., Orłowski, D. (2009). Szlak Oscypkowy jako nowy produkt turystyczny Podhala. W: M. Jalinik (red.), Konkurencyjność produktów turystycznych. Białystok: Oficyna Wydawnicza Politechniki Białostockiej, 100-112.

Woźniczko, M., Orłowski, D. (2011a). Szlaki kulinarne komponentem wiejskiego produktu turystycznego. W: C. Jastrzębski (red.), Turystyka wiejska na drodze do komercjalizacji. Kielce: Wyd. Wyższa Szkoła Ekonomii i Prawa im. prof. Edwarda Lipieńskiego w Kielcach, 101-123.

Woźniczko, M., Orłowski, D. (2011b). Lubuski Szlak Wina i Miodu oraz jego kulturowe znaczenie dla rozwoju turystyki winiarskiej. W: B. Sawicki, J. Janicka (red.), Wielowymiarowe aspekty turystyki kulturowej. Lublin: Wyd. Uniwersytet Przyrodniczy w Lublinie, 158-174.

Woźniczko, M., Orłowski, D. (2014). Funkcjonowanie szlaków kulinarnych na Mazowszu. W: P. Dominik (red.), Szlaki kulinarne jako element turystycznej atrakcyjności regionu Mazowsze. Warszawa: Oficyna Wydawnicza ASPRA-JR, 133.

Wysokińska, B. (2014). Elementy historyczne w tworzeniu i rozwoju szlaków kulinarnych Mazowsza. Funkcjonowanie szlaków kulinarnych na Mazowszu. W: P. Dominik (red.), Szlaki kulinarne jako element turystycznej atrakcyjności regionu Mazowsze. Warszawa: Oficyna Wydawnicza ASPRA-JR, 51.

Zadrożna, D. (2014). Konsorcjum Produktowe „Szlaki Kulinarne” w ramach inicjowania, tworzenia i zarządzania partnerskimi grupami produktowymi. W: P. Dominik (red.), Szlaki kulinarne jako element turystycznej atrakcyjności regionu Mazowsze. Warszawa: Oficyna Wydawnicza ASPRA-JR, 207. 
Piotr Dominik, dr inż., absolwent Wydziału Technologii Żywności SGGW. Ukończył studia doktoranckie z zakresu oceny jakości żywności. Ze względu na profil zainteresowań jest aktywnie związany $\mathrm{z}$ branżą hotelarską i gastronomiczną przez pracę $\mathrm{w}$ organizacjach branżowych oraz działalność trenerską. Jest autorem podręczników akademickich, rozdziałów w monografiach oraz artykułów naukowych z zakresu żywienia, gastronomii i hotelarstwa. Obecnie pracuje jako adiunkt w Szkole Głównej Turystyki i Rekreacji w Warszawie. Tematy badawcze, którymi się zajmuje, to m.in.: wpływ preparatów błonnikowych na cechy jakościowe pieczywa; tworzenie szlaków kulinarnych w świetle zwiększania atrakcyjności turystycznej regionu; tradycyjne produkty kulinarne jako element turystycznej atrakcyjności Mazowsza; aktywność systemów gastronomicznych na polskim rynku oraz ich udział w obsłudze ruchu turystycznego. Piotr Dominik był organizatorem konferencji i seminariów naukowych i branżowych, w tym konferencji zorganizowanej we współpracy z Urzędem Marszałkowskim Mazowsza pt. „Szlaki kulinarne jako element turystycznej atrakcyjności regionu - Mazowsze".

Piotr Dominik, PhD of Agricultural Sciences. Graduate of the Department of the SGGW Food Technology. Finished doctoral studies from the scope of the assessment of the food quality. Piotr Dominik is an author of textbooks, academic chapters in monographs and scientific papers on feeding, gastronomy and the hotel trade. Assistant Professor in the Warsaw School of Tourism and Hospitality Management. Research topics include: influence of the cellulose formulations on the qualitative features of bread; creating the culinary trails in the light of increasing the touristic attractiveness of the region; traditional culinary products as an element of touristic attractiveness of the Masovia region; activity of the gastronomic systems on the Polish market and their participation in servicing the touristic traffic. Piotr Dominik was an organizer of scientific and business conferences and seminars, including the conference organized in cooperation with the Marshall Office of Masovia entitled "Culinary Trails as an Element of the Touristic Attractiveness of the Region - Masovia".

\section{Adres/Address:}

Szkoła Główna Turystyki i Rekreacji

ul. Stokłosy 3

02-787 Warszawa, Polska

e-mail: piotrdominik@autograf.pl 